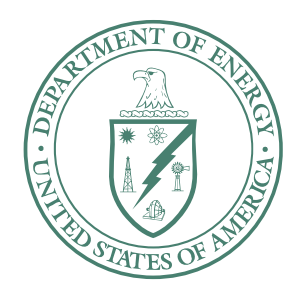

U.S. Department of Energy

Idaho Operations Office

\title{
Operable Unit 3-14, Tank Farm Soil and INTEC Groundwater Remedial Design/Remedial Action Scope of Work
}

July 2007 

DOE/ID-11318

Revision 0

Project No. 23512

\section{Operable Unit 3-14, Tank Farm Soil and INTEC Groundwater Remedial Design/Remedial Action Scope of Work}

July 2007

Prepared for the 



\begin{abstract}
This Remedial Design/Remedial Action (RD/RA) Scope of Work pertains to OU 3-14 Idaho Nuclear Technology and Engineering Center and the Idaho National Laboratory and identifies the remediation strategy, project scope, schedule, and budget that implement the tank farm soil and groundwater remediation, in accordance with the May 2007 Record of Decision. Specifically, this RD/RA Scope of Work identifies and defines the remedial action approach and the plan for preparing the remedial design documents.
\end{abstract}




\section{CONTENTS}

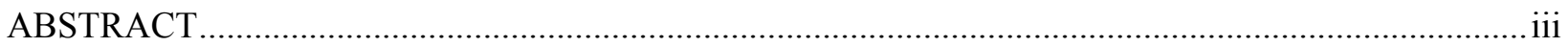

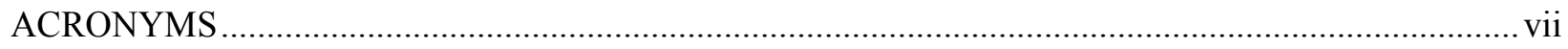

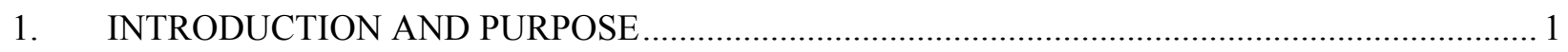

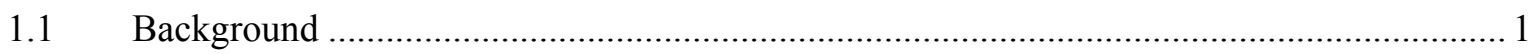

1.2 Remedial Action Objectives..................................................................................... 3

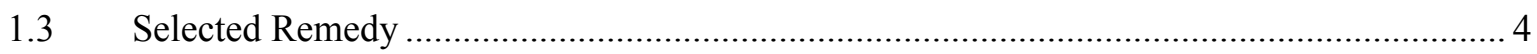

1.4 General Requirements, Applicable or Relevant and Appropriate Requirements, and

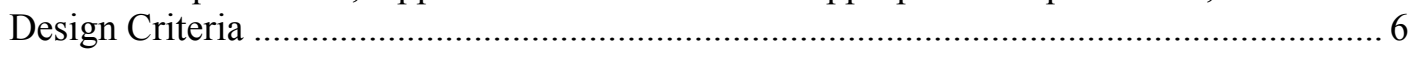

2. ASSUMPTIONS, LIMITING FACTORS, AND CONDITIONS …............................................ 6

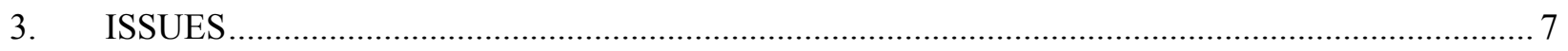

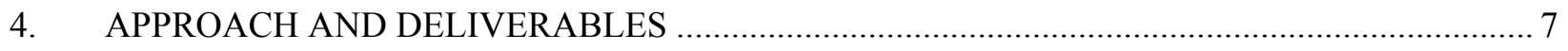

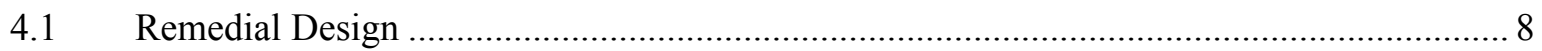

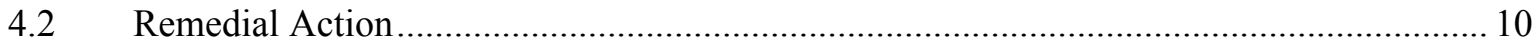

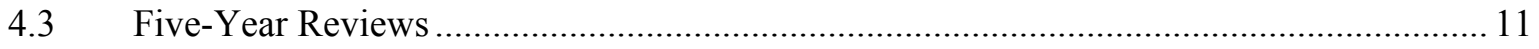

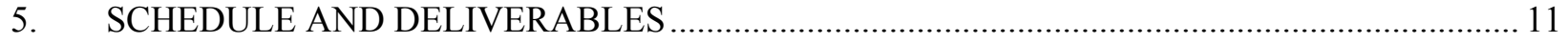

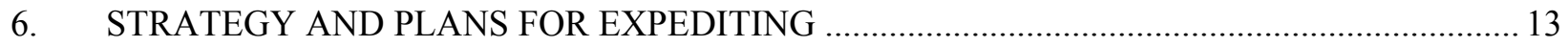

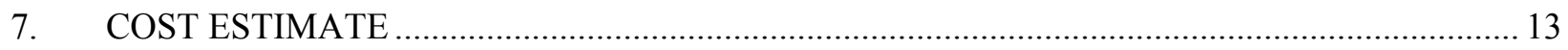

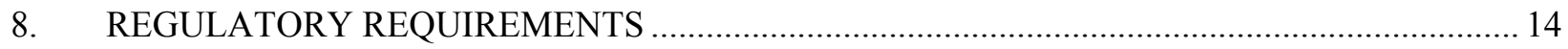

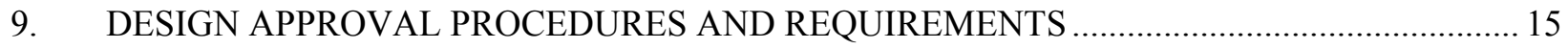

9.1 Plans for Disposition of Changed Conditions ….................................................... 15

10. CORRELATION BETWEEN PLANS AND SPECIFICATIONS ........................................... 16

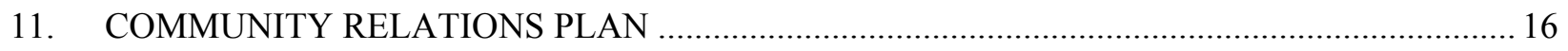

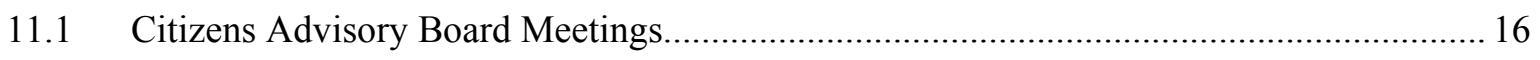

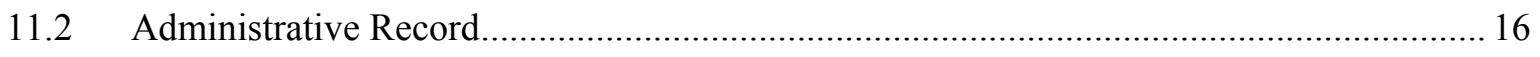

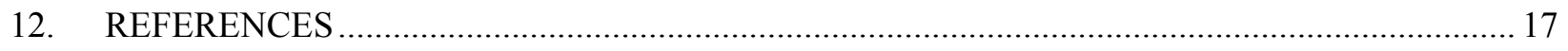


Appendix A-Waste Area Group 3 Operable Unit 3-14 Remedial Design/Remedial Action

Working Schedule

\section{FIGURE}

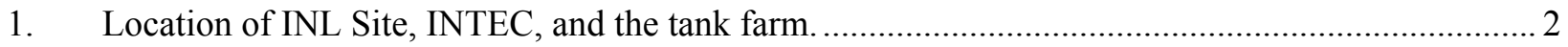

2. Location of north, central, and south tank farm, recharge control zone; active and inactive

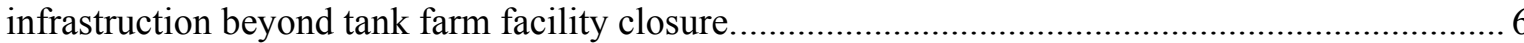

\section{TABLES}

1. Deliverable Schedule for OU 3-14 RD/RA draft documents to EPA and DEQ........................... 12

2. Estimated capital cost of the Operable Unit 3-14 final remediation............................................. 13

3. Estimated operations and maintenance and periodic cost of the Operable Unit 3-14 final

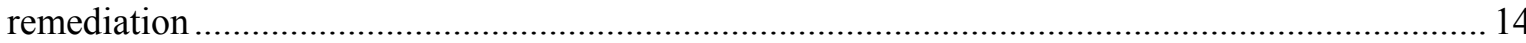

4. Summary of costs of the Operable Unit 3-14 final remediation................................................... 14 


\section{ACRONYMS}

ARAR applicable or relevant and appropriate requirement

CERCLA Comprehensive Environmental Response, Compensation, and Liability Act

CPP Chemical Processing Plan (also ICPP, Idaho Chemical Processing Plant)

DD\&D deactivation, decontamination, and decommissioning

DEQ Idaho Department of Environmental Quality

DOE U.S. Department of Energy

DOE-ID U.S. Department of Energy Idaho Operation Office

EPA U.S. Environmental Protection Agency

ET/CB Evapotranspiration/capillary biobarrier

FFA/CO Federal Facility Agreement and Consent Order

ICDF Idaho CERCLA Disposal Facility

INEEL Idaho National Engineering and Environmental Laboratory

INL Idaho National Laboratory (formerly INEEL)

INTEC Idaho Nuclear Technology and Engineering Center

IWTU Integrated Waste Treatment Unit

O\&M operations and maintenance

OU operable unit

RA remedial action

RCRA Resource Conservation and Recovery Act

$\mathrm{RD} \quad$ remedial design

$\mathrm{RD} / \mathrm{RA} \quad$ remedial design/remedial action

RI/FS remedial investigation/feasibility study

ROD record of decision

SOW scope of work

SRPA Snake River Plain Aquifer 


\section{Operable Unit 3-14, Tank Farm Soil and INTEC Groundwater Remedial Design/Remedial Action Scope of Work}

\section{INTRODUCTION AND PURPOSE}

In accordance with the Idaho National Engineering and Environmental Laboratory (INEEL) Federal Facility Agreement and Consent Order (FFA/CO) (DOE-ID 1991), the U.S. Department of Energy Idaho Operations Office submits this Remedial Design/Remedial Action (RD/RA) Scope of Work (SOW) for the remediation of the tank farm soil and Idaho Nuclear Technology and Engineering Center (INTEC) groundwater under Operable Unit (OU) 3-14. The RD/RA identified in this SOW-as part of the Comprehensive Environmental Response Compensation and Liability Act (CERCLA) process —will proceed in accordance with the Record of Decision for Tank Farm Soil and INTEC Groundwater, Operable Unit 3-14, (DOE-ID 2007) signed on May 14, 2007.

The purpose of this RD/RA Scope of Work is to identify the remediation strategy, project scope, schedule, and budget necessary to initiate the implementation of the tank farm soil and INTEC groundwater remediation, through the $\mathrm{RD} / \mathrm{RA}$ work plan, in accordance with the requirements and objectives of the OU 3-14 Record of Decision (ROD).

\subsection{Background}

The INTEC tank farm, built from the early 1950s through the mid 1960s, is an integral part of the former Chemical Processing Plant (CPP, also called the Idaho Chemical Processing Plant [ICPP]) (see Figure 1). The CPP was built to reprocess spent nuclear fuel and recover and recycle uranium-235 (U-235) and other nuclear materials. Wastes from reprocessing were stored underground in stainless steel tanks. Most of these wastes have been removed from the tanks for treatment and have been concentrated in evaporators and/or converted into solids through a process called calcining.

From a CERCLA perspective, the term "tank farm" refers to the underground tanks used to store radioactive liquid wastes, the infrastructure used to transfer, monitor, and control the liquid wastes, and the surrounding soil within the tank farm boundary. Some of the piping and valves outside the tanks and vaults leaked, contaminating soil, perched water, and groundwater. Some of the leaks were a result of flaws in piping or valve designs that were corrected during several major upgrades. The leaks and spills occurred mainly between 1954 and 1986. No known leaks have occurred from the tanks.

Another source of contamination to the subsurface was the former INTEC injection well, CPP-23, (see Figure 1). It was used from the early 1950s to the mid 1980s for the routine discharge of service wastewater to the Snake River Plain Aquifer (SRPA). Twice, during the well's use, wastewater was briefly discharged into the vadose zone (DOE/NE-ID 2006a). The well was sealed and abandoned in 1989.

The Idaho National Laboratory (INL) Site was placed on the National Priorities List of CERCLA hazardous substance release sites in 1989 (40 CFR 300) and became subject to the provisions of CERCLA $\S 120$ (42 USC § 9620) governing remedial action at federal facilities. In 1991, the Agencies (Idaho Department of Environmental Quality [DEQ], Environmental Protection Agency [EPA], and Department of Energy Idaho Operations Office [DOE-ID]) signed a Federal Facility Agreement and Consent Order (FFA/CO) and Action Plan (DOE-ID 1991) governing CERCLA cleanups and Hazardous Waste Management Act/Resource Conservation and Recovery Act (RCRA) corrective actions on the INL Site. 


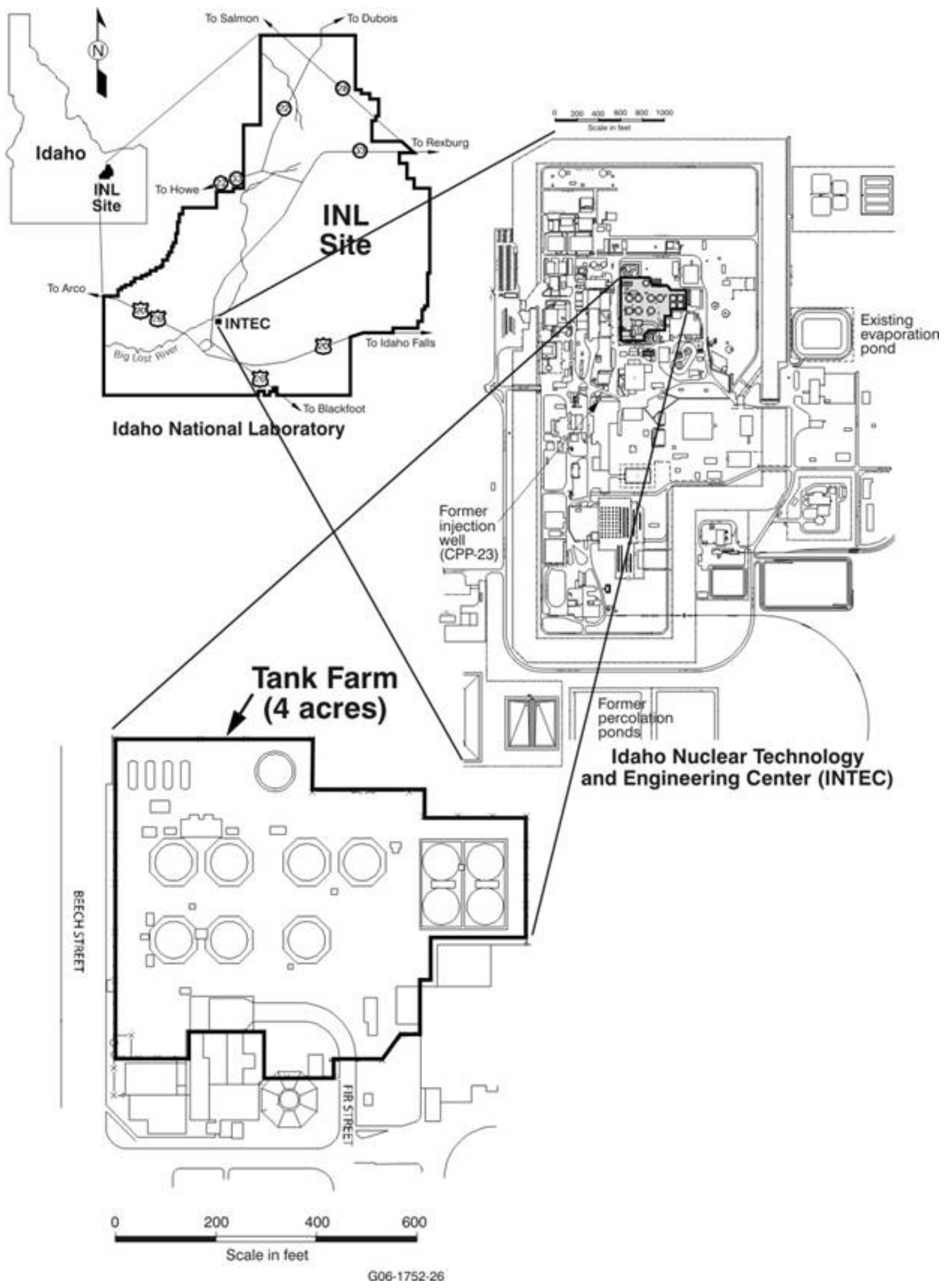

Figure 1. Location of INL Site, INTEC, and the tank farm. 
Under the terms of CERCLA $\S 120$ as implemented through the FFA/CO, DOE will carry out the cleanup and pay for associated costs.

The FFA/CO placed known CERCLA release sites at INTEC in OU 3-13, and required a comprehensive remedial investigation/feasibility study (RI/FS) for this OU. Known release sites within INTEC in 1997 were evaluated in the OU 3-13 Comprehensive RI/FS (DOE-ID 1997a, 1997b). Ninety-five release sites were evaluated in the remedial investigation, 40 of which exceeded the soil remedial action objectives and were, therefore, further evaluated for remedial alternatives in the feasibility study. In 1999, the Agencies signed the ROD for OU 3-13 (DOE-ID 1999). As part of the OU 3-13 ROD, the Agencies determined that they needed more information before they could make a final remedial action decision on tank farm soils and INTEC groundwater. Information needed included:

- The nature and extent of contamination in the tank farm and nearby soil, as well as the impact of this contamination on groundwater

- Whether the former injection well was a continuing source of contamination to groundwater

- $\quad$ How a planned environmental impact statement (EIS) (DOE 2002, DOE 2005) for disposition of the waste in the tank farm facility tanks would affect the decision for contaminated soil surrounding the tanks.

To address the need for additional information, the Agencies created OU 3-14 to conduct further investigations and select a final remedy for tank farm soil and groundwater, while interim actions were being implemented under the OU 3-13 ROD (DOE-ID 1999). The final remedy for tank farm soil and INTEC groundwater in the OU 3-14 ROD supersedes the OU 3-13 interim actions.

\subsection{Remedial Action Objectives}

The remedial action objectives provide a general description of what the CERCLA cleanup is designed to accomplish and serve as the design basis for the selected remedy as identified in Section 1.3. Remedial action objectives for the SRPA affected by INTEC sources are defined as follows:

I. Prior to 2095, prevent current workers and the general public from ingesting SRPA groundwater contaminated by INTEC releases that exceeds (1) maximum contaminant levels, currently identified as $8 \mathrm{pCi} / \mathrm{L}$ for $\mathrm{Sr}-90,900 \mathrm{pCi} / \mathrm{L}$ for Tc-99, $1 \mathrm{pCi} / \mathrm{L}$ for $\mathrm{I}-129$, and $10 \mathrm{mg} / \mathrm{L}$ for nitrate measured as nitrogen; (2) a cumulative excess cancer risk from all carcinogens of 1 in 10,000; or (3) an hazard index of 1.

II. In 2095 and beyond, ensure that concentrations of all contaminants in SRPA groundwater contaminated by INTEC releases do not exceed (1) maximum contaminant levels; (2) a cumulative excess cancer risk from all carcinogens of 1 in 10,000; or (3) an hazard index of 1.

Remedial action objectives for the OU 3-14 soil are defined as follows:

III. Prevent external exposure to current and future workers inside the tank farm boundary from Cs-137 contaminated alluvium and prevent biotic transport that would exceed an excess cancer risk of 1 in 10,000 .

IV. Prevent external exposure to current workers at Sites CPP-15 and CPP-58 from Cs-137 contaminated alluvium that would exceed an excess cancer risk of 1 in 10,000. 
V. Prevent internal exposure to biological receptors from Cs-137 and Sr-90 inside the tank farm boundary that would exceed an ecological hazard quotient of 10 for an individual contaminant and a total ecological hazard index of 10 .

A detailed discussion of the remedial action objectives is contained in Section 8 of the OU 3-14 ROD.

\subsection{Selected Remedy}

The selected remedy for OU 3-14 consists of remedial actions for tank farm soil and groundwater and no action for a group of sites outside the tank farm. Major components of the selected remedy are summarized below, beginning with items that are common to all time periods (items 1 through 4), and ending with items that are specific to a time period (items 5 through 7):

1. Institutional controls will be implemented to prevent exposure to the contaminated soil and groundwater and prevent land uses that would be inconsistent with the selected remedy. The institutional controls include restrictions to (a) eliminate or minimize exposure to contaminated soil or groundwater; (b) limit disturbances of contaminated tank farm soil by non-CERCLA activities; (c) prohibit the use of the portion of the SRPA in proximity to INTEC that exceeds maximum contaminant levels; and (d) control drilling activities that could cause potential cross contamination between contaminated perched water and the SRPA. These controls will be included in the INL Sitewide Institutional Controls Plan.

2. Contaminant concentrations and water levels in perched water and SRPA indicator wells will be monitored in accordance with a long-term monitoring plan to assist in determining the effectiveness of the groundwater remedy and to ensure that the portions of the SRPA contaminated by INTEC releases will meet maximum contaminant levels by 2095 .

3. The selected remedy for 16 sites outside the tank farm boundary is no action under CERCLA. Three of these sites (CPP-125, CPP-126, and CPP-128) involved leaks or releases of nonradioactive, nonhazardous steam condensate or service wastewater and, therefore, require no action. The remaining 13 no action sites (CPP-102, CPP-103, CPP-104, CPP-105, CPP-106, CPP-107, CPP-108, CPP-109, CPP-110, CPP-113, CPP-114, CPP-115, and CPP-116) are shallow injection wells associated with the steam system. Releases associated with these sites do not pose an unacceptable risk to human health or the environment based on unlimited use and unrestricted exposures and, therefore, do not require CERCLA remediation or implementation of institutional controls. Therefore, with the no action decision in the OU 3-14 ROD, the sites will exit the CERCLA process.

4. If historic releases to the environment are discovered after the ROD is implemented, this contamination will be addressed using the process the Agencies have established for evaluation and inclusion of new sites under the FFA/CO. Using this process, a newly identified release is evaluated and, if the contaminants are addressed in an existing ROD, the Agencies may determine that the site may be remediated under the existing ROD. These sites will undergo evaluation during the five-year review process to assess whether the actions taken are sufficient to protect human health and the environment. To protect workers, the public, and the environment, the institutional controls for newly identified sites will be implemented using the controls in place for similar sites in the operable unit. 
5. Prior to tank farm facility closure, these major components will be implemented:

- Install and maintain a low-permeability pavement (or equivalent barrier to reduce infiltration) over the recharge control zone outside the tank farm with expanded drainage system to reduce infiltration of precipitation without interfering with ongoing INTEC operations and remediation activities. Direct water run-off to lined ditches, which will divert it to an evaporation pond. As buildings and structures are removed through deactivation, decontamination, and decommissioning (DD\&D), extend the low-permeability pavement over decommissioned areas as soon as they become available to maintain an infiltration-reducing barrier over the recharge control zone outside the tank farm.

- $\quad$ Maintain the Tank Farm Interim Action system per the operations and maintenance (O\&M) plan until the selected remedy's drainage and water management system is expanded. Approval of the OU 3-14 RD/RA work plan, and expansion, completes the Tank Farm Interim Action.

- $\quad$ Implement and maintain additional recharge controls in northern INTEC to reduce anthropogenic and storm water recharge to the northern perched water zones.

- $\quad$ Monitoring of groundwater will continue and institutional controls will be maintained.

6. Following tank farm facility closure, these major components will be implemented:

- Install a low-permeability pavement (or equivalent barrier to reduce infiltration) over the north, central, and south tank farm to reduce infiltration of precipitation (see Figure 2). Direct captured surface water run-off to lined ditches, culverts, and lift station(s) for transport to the lined evaporation pond.

- Maintain the drainage system and low-permeability pavement over the recharge control zone to reduce infiltration of precipitation without interfering with ongoing INTEC cleanup operations.

- Maintain the recharge controls in northern INTEC to reduce anthropogenic and storm water recharge sources to the northern perched water zones.

- $\quad$ Monitoring of groundwater will continue and institutional controls will be maintained.

7. As part of and coordinated with INTEC facility closure, these major components will be implemented:

- Install a protective cover over the north tank farm. Use characterization results to design the protective cover (i.e., maintain the low-permeability pavement, excavate soil and replace with clean backfill and new low-permeability pavement or equivalent barrier to reduce infiltration, or extend the evapotranspiration cap with capillary biobarrier [ET/CB] that is to be placed over the central area and south tank farm area).

- Install an ET/CB over the central and south tank farm to protect workers from exposure.

- $\quad$ Monitor and maintain the ET/CB, low-permeability pavement, and drainage system to reduce infiltration of precipitation. 


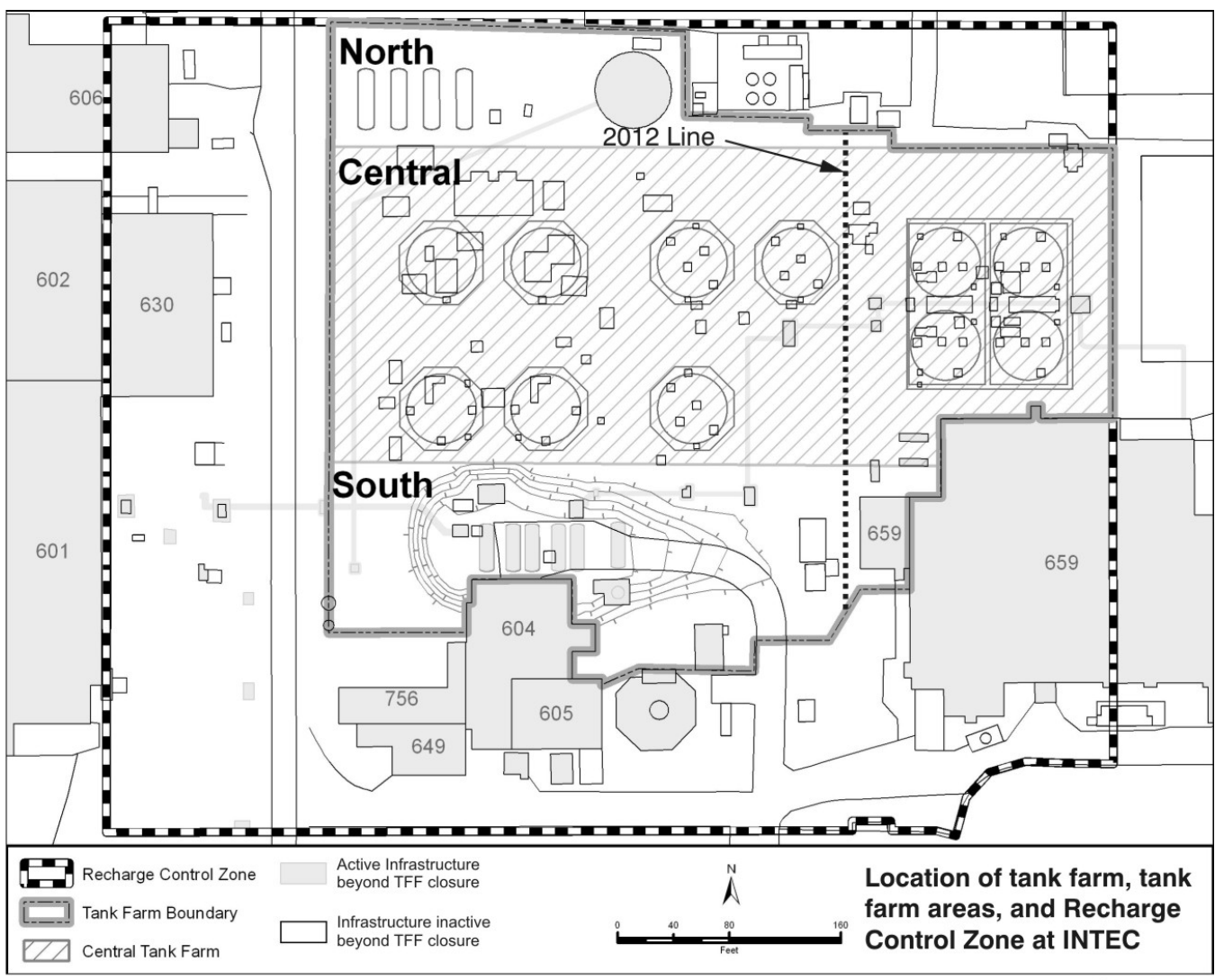

G07-1995-01

Figure 2. Location of north, central, and south tank farm, recharge control zone; active and inactive infrastruction beyond tank farm facility closure.

\subsection{General Requirements, Applicable or Relevant and Appropriate Requirements, and Design Criteria}

The applicable or relevant and appropriate requirement (ARARs) that apply to the tank farm soil and INTEC groundwater are identified in the OU 3-14 ROD Table 13-1. These ARARs will be used along with other applicable DOE and INL requirements to provide the complete design criteria for the tank farm soil and INTEC groundwater remediation. As part of the design process, an implementation approach for the ARARs will be developed and will be identified in the RD/RA work plan(s).

\section{2. $\quad$ ASSUMPTIONS, LIMITING FACTORS, AND CONDITIONS}

The bounding assumptions, limiting factors, and conditions under which the RD/RA activities will be performed include:

1. The Idaho CERCLA Disposal Facility (ICDF) or other approved disposal facility on or off the INL will be available for OU 3-14 waste disposal. The ICDF may not be available after 2012.

2. Remedial action will be performed in phases to coordinate with on-going tank farm closure, DD\&D inside/outside of the tank farm within the recharge control zone, and INTEC facility closure.

3. Remediation schedules will be based on the available funding. 
4. Monitoring will be performed as part of RD/RA and is separate from institutional controls.

5. Institutional controls will be managed per the requirements stated in the INL Sitewide Institutional Controls Plan, which is scheduled to be revised by November 14, 2007.

6. Any contaminated materials removed in preparation for construction of low-permeability pavement or the ET/CB will meet the ICDF waste acceptance criteria and be placed in the ICDF facility.

\section{ISSUES}

Currently, no significant unresolved issues are identified for the implementation of the OU 3-14 remedy.

The implementation will require coordination with other projects that are active in the same geographic area of INTEC (e.g., DD\&D planning for CPP-601, tank farm closure, Integrated Waste Tracking Unit [IWTU], and tank farm DD\&D). The schedule and sequence of activities will be prepared for the OU 3-14 remedy implementations with the assumption that projects to coordinate with will remain on schedule. The approach and schedule (with alternatives) are discussed in Sections 4 and 5, respectively.

\section{APPROACH AND DELIVERABLES}

Implementation of the remedy will consist of two elements: (1) remedial design, and (2) remedial action. The remedial design includes designs and specifications in the work plans and secondary design documents. The remedial action includes field construction activities, institutional controls, long-term operations and maintenance, five-year reviews, and monitoring.

The design and action elements will proceed through three phases, defined as:

Phase I-Remedial design and actions taken to place the low-permeability pavement over the recharge control zone outside the tank farm fence. Associated Phase I design and actions include implementation of recharge and runoff controls, institutional controls, operation and maintenance, five-year reviews, and monitoring.

Phase II-Remedial design and actions following tank farm closure and DD\&D of tank farm structures. Phase II actions include installation of low-permeability pavement over the north, central, and south tank farm; continued implementation of recharge and runoff controls; institutional controls; operation and maintenance; five-year reviews; and monitoring.

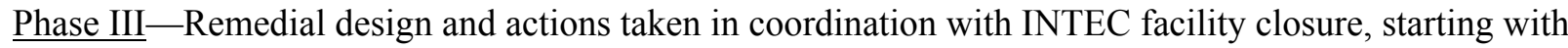
north tank farm soil characterization and installation of the ET/CB. Characterization results will be used to determine the final cover for the north tank farm (leave low-permeability pavement in place, excavate and backfill with clean soil and replace the low-permeability pavement, or extend the ET/CB over the area). The ET/CB will be placed over the central and south tank farm areas (and extend over the north area as necessary). Continued actions in Phase III include recharge and runoff controls, institutional controls, operation and maintenance, five-year reviews, and monitoring.

Section 4.1 provides a description of Phase I, II, and III remedial design deliverables and scope. Section 4.2 provides a description of Phase I, II, and III remedial action deliverables and requirements. Section 4.3 describes the five-year review process. 


\subsection{Remedial Design}

A single RD/RA work plan will be prepared for the three phases of the selected remedy. The work plan will include finalized design for Phase I, conceptual (30\% complete) designs for Phases II and III, plus any applicable supporting documents. A secondary design document containing a $90 \%$ design for Phase II will be delivered to the Agencies by November 2011 for review. In addition, a secondary design document containing a $90 \%$ design for Phase III will be delivered to the Agencies after INTEC facility closure for review.

The OU 3-14 RD/RA work plan will detail activities for the implementation of the selected remedy and will be submitted as a primary document under the FFA/CO (DOE-ID 1991). The work plan will include:

- $\quad$ Design drawings and specifications

- $\quad$ Detailed cost estimate for remedial action activities for Phase I

- $\quad$ Rough order of magnitude cost estimate for remedial action activities for Phases II and III

- $\quad$ Remedial action schedule for Phase I and conceptual schedule for Phases II and III

- Identification of primary and secondary documents and dates of submittal (by date and in relation to activities of other programs for Phases II and III)

- Description of how the proposed remedial design and remedial action will meet substantive aspects of the ARARs identified in the OU 3-14 ROD (DOE-ID 2007 - Section 11.2)

- $\quad$ Discussion of any changes from the ROD, if applicable

- Identification of remedial action inspections, problems, and reports

Supporting documents to the RD/RA work plan will include:

- $\quad$ Operations and maintenance $(\mathrm{O} \& \mathrm{M})$ plan

- Waste management plan

- $\quad$ Characterization plan

- $\quad$ Project-specific monitoring plan.

\subsubsection{Scope}

The scope of the remedial design for the OU 3-14 remedial actions is described in the following subsections. No other design documents will be submitted formally before submittal of the draft RD/RA work plan. The actions are presented in the anticipated order of implementation, although the first three actions are in part, currently ongoing, will continue to be implemented simultaneously, and continue throughout the remedial action timeframe. The remedy selected in the OU 3-14 ROD supersedes the OU 3-13 interim remedy for Group 1 (Tank Farm Interim Action) and Group 5 (SRPA). Operation and maintenance of the Tank Farm Interim Action components plus SRPA monitoring will continue under OU 3-14 upon finalization of the RD/RA work plan. 
4.1.1.1 Recharge and runoff controls (Phases I and II). Recharge and runoff controls will be implemented and maintained in northern INTEC to reduce anthropogenic and storm water recharge to the northern perched water zones. These controls will include activities such as:

- $\quad$ Capture roof runoff and divert to an evaporation pond

- $\quad$ Perform a regular facility water balance to help detect subsurface water discharges

- $\quad$ Line additional drainage ditches and divert to an evaporation pond.

The water balance and maintenance actions for the recharge and runoff controls will be documented in an annual operations report.

4.1.1.2 Institutional Controls (Phases I, II, and III). Institutional controls will be implemented and include restrictions to prevent unacceptable exposure to contaminated soil or groundwater; limit disturbances of contaminated tank farm soil by non-CERCLA activities; prohibit the use of the portion of the SRPA in proximity to INTEC that exceeds maximum contaminant levels; and control drilling activities that could cause potential cross contamination between contaminated perched water and the SRPA. These controls will be included in the updated INL Sitewide Institutional Controls Plan.

4.1.1.3 Monitoring (Phases I, II, and III). Contaminant concentrations and water elevations in perched water and SRPA indicator wells will be monitored in accordance with a long-term monitoring plan to assist in determining the effectiveness of the OU 3-14 remedy and to ensure that the portions of the SRPA contaminated by INTEC releases will have concentrations below maximum contaminant levels by 2095. Monitoring of perched water under OU 3-13, Group 4 and monitoring of the SRPA under OU 3-13, Group 5 will continue until incorporated into an OU 3-14 long-term monitoring plan.

4.1.1.4 Operation and Maintenance (Phases I, II, and III). Long-term operation and maintenance of the facility and remedial actions are required; details will be in the supporting operation and maintenance plan to the RD/RA work plan. Components of the OU 3-13, Group 1, Tank Farm Interim Action (such as lined ditches, lift station, and evaporation pond) will be brought into and maintained under OU 3-14 upon finalization of the RD/RA work plan. As part of operation and maintenance, as buildings and structures are removed within the recharge control zone (see Figure 2) through DD\&D activities, the low-permeability pavement will be extended over the former building and structure areas (as soon as they become available) to maintain an infiltration-reducing barrier. Operation and maintenance activities will be documented in an annual operations report.

\subsubsection{Installation of Low-Permeability Pavement and Expanded Drainage System}

(Phase I). Open areas within the recharge control zone outside the tank farm will be covered with low-permeability pavement. This type of barrier can be readily installed around existing infrastructure and can be easily expanded as facility infrastructure is removed. This barrier will require (1) ongoing maintenance (such as patching) to ensure its effectiveness, and (2) use of lift stations to transport accumulated surface water to an existing lined evaporation pond. The existing drainage system will be expanded to accommodate the increased expected runoff that will be diverted to an evaporation pond. As buildings and structures are removed through DD\&D, the low-permeability pavement will be extended to maintain infiltration reduction over the recharge control zone.

\subsubsection{Installation of Low-Permeability Pavement and Expanded Drainage System}

(Phase II). The north, central, and south tank farm areas (see Figure 2) will be covered with low-permeability pavement. This barrier will require ongoing monitoring and maintenance to ensure captured surface water is successfully diverted to an existing lined evaporation pond. The surfaces will be 
sufficiently sloped to accommodate the accumulated surface water to the existing drainage system outside the tank farm.

4.1.1.7 North Tank Farm Action (Phase III). The north tank farm soil will be characterized as part of INTEC facility closure. Characterization results will be used to design the protective cover (e.g., maintain the low-permeability pavement, excavate soil and replace with clean backfill and new low-permeability pavement, or extend the ET/CB that is placed over the central and south areas).

4.1.1.8 Installation of the ET/CB (Phase III). The central and south tank farm will have an ET/CB installed to prevent unacceptable exposure to workers. The multiple layers of soil, liner, and gravel provide both worker protection and reduce infiltration of precipitation. Although the ET/CB requires less maintenance than the low-permeability pavement, it will be monitored and maintained, as will the low-permeability pavement and drainage system, through the remedial action timeframe. If determined to be more cost effective than maintaining the low-permeability pavement, the ET/CB can be expanded.

\subsection{Remedial Action}

In accordance with CERCLA requirements, the remedial action activities will begin by August 14, 2008. The remedial action will consist of the field work required to perform the work as described in the ROD and specified in the RD/RA work plan and later secondary design documents for Phases II and III.

The RD/RA work plan will establish the schedule and deliverables for remedial action. The work plan will incorporate, by reference, pertinent aspects of the SOW and will:

- $\quad$ Specify any relevant changes in the content of the SOW arising from the design effort

- $\quad$ Update schedules in the SOW by including dates for the submittal of primary and secondary documents of the remedial action work element

- Update the cost estimate for remedial action

- Identify additional remedial action secondary documents.

Secondary design documents will be submitted approximately six months prior to the start of remedial action work activities for Phases II and III. The secondary design documents will provide the details required to construct the remedial components.

General remedial action deliverables will include prefinal inspection reports (after each phase), a completion report (after completion of Phases I and II), and a remedial action report (after completion of Phase III). The prefinal inspection reports will include:

- $\quad$ Outstanding construction requirements

- $\quad$ Prefinal inspection checklist

- $\quad$ Actions required to resolve outstanding items

- $\quad$ Projected completion dates

- $\quad$ Date of the final inspection. 
The completion report and remedial action report will be submitted as FFA/CO primary documents. The reports will provide an overview of the remedial activities, including any changes to the remedial design. The reports will include:

- A brief description of outstanding items from the prefinal inspection report and how these items were resolved

- Identification of work defined in the RD/RA work plan and certification that the work was performed

- Explanation of any modification to the RD/RA work plan

- $\quad$ Certification that the selected remedy Phase is operational and functional (remedial action report only)

- $\quad$ Documentation necessary to support deletion of a site from the National Priorities List

(54 FR 48184), as appropriate (remedial action report only).

An operation and maintenance report shall be prepared and delivered to the Agencies each year that documents the status of the remedy and inspection and maintenance actions performed to maintain the remedy components. In addition, the operations report will contain the data and interpretations regarding a water balance for the northern INTEC area that includes but is not limited to precipitation, estimated evaporation (and transpiration if applicable), water line leaks, wastewater line leaks, water discharges such as fire-water line tests, northern shallow perched groundwater level changes, and storm water captured and discharged to the evaporation pond. A more comprehensive analysis will be prepared and submitted to the Agencies every five years, as part of the five-year review.

\subsection{Five-Year Reviews}

For those sites where contaminants are to be left in place in concentrations in excess of levels that will allow for unlimited use and unrestricted exposure, a review will be conducted at least every five years after the initiation of the first remedial action. The statutory five-year review will be conducted to ensure that the remedy is effectively protecting human health and the environment. The five-year review will evaluate such factors as contaminant migration from sites where contamination has been left in place, effectiveness of institutional controls, and overall effectiveness of the remedial actions. Five-year reviews will be conducted for remediated sites with institutional controls until it has been determined during a five-year review that controls and reviews are no longer necessary. Required five-year reviews will be coordinated with the sitewide five-year review for the INL per the Idaho National Engineering and Environmental Laboratory Sitewide Five-Year Review Plan for CERCLA Response Actions (DOE/NE-ID 2004a).

The first sitewide comprehensive five-year review was performed in 2006 (DOE/NE-ID 2006b). The next INL Site five-year review is scheduled for completion in 2011 and will include the review of OU 3-14 activities.

\section{SCHEDULE AND DELIVERABLES}

A schedule containing tasks to complete the RD/RA work plan and perform the remedial actionsthrough completion of the remedial action report (after INTEC facility closure) - is listed in Appendix A. Remedial action activities will begin by August 14, 2008. 
Installation of the low-permeability pavement inside the tank farm will begin in the spring of 2012, and as much of the tank farm as is available by August 2012 will be covered. If the tank farm closure project is completed by early 2012, the plan is to pave the entire tank farm area. However, if the tank farm closure project is not completed, the low-permeability pavement is scheduled to be installed west of the "2012 Line" illustrated in Figure 2. The remainder of the tank farm eastern corner will be covered during the next construction season following tank farm closure.

Preparation and implementation of the Phase III remedial activities (ET/CB construction and associated activities) is linked to INTEC facility closure. Currently, INTEC facility closure is planned for completion in 2035. Finalization of the Phase III RD/RA design drawings will begin after INTEC closure, and installation will begin during the next available construction season following closure.

Table 1 shows EPA and DEQ deliverables, document type, and enforceable milestones either as a date or tied to an event. As previously noted, completion of RD/RA activities will be coordinated with other INTEC projects. Completion of Phase I will be prior to tank farm closure, as much of Phase II will be completed by September 2012 with the remainder completed during the next construction season following tank farm closure, and completion of Phase III will be after INTEC facility closure.

Table 1. Deliverable Schedule for OU 3-14 RD/RA draft documents to EPA and DEQ.

\begin{tabular}{|c|c|c|}
\hline Deliverable & $\begin{array}{c}\text { Documer } \\
\text { Type }^{\mathrm{a}}\end{array}$ & Enforceable Milestone \\
\hline Draft RD/RA Scope of Work & NA & N/A \\
\hline Draft RD/RA Work Plan & Primary & February 21, 2008 \\
\hline Phase I Prefinal Inspection Report & Secondary & $\mathrm{N} / \mathrm{A}$ \\
\hline 90\% Design Document, Phase II & Secondary & N/A \\
\hline $\begin{array}{l}\text { Phase II Prefinal Inspection Report for Activities } \\
\text { Completed Sept } 2012\end{array}$ & Primary & October 9, 2012 \\
\hline $\begin{array}{l}\text { Phase II Prefinal Inspection Report - Phase II } \\
\text { Completed (if necessary) }\end{array}$ & Secondary & $\mathrm{N} / \mathrm{A}$ \\
\hline Draft Completion Report for Phases I and II & Primary & $\begin{array}{l}\text { Within } 60 \text { days of the final inspection } \\
\text { for Phase II }\end{array}$ \\
\hline 90\% Design Document, Phase III & Secondary & \\
\hline Draft Remedial Action Report & Primary & $\begin{array}{l}\text { Within } 60 \text { days of the final inspection } \\
\text { for Phase III }\end{array}$ \\
\hline O\&M Report ${ }^{\mathrm{b}}$ & Secondary & \\
\hline Draft Revised Institutional Controls Plan & & November 14, 2007 \\
\hline \multicolumn{3}{|c|}{$\begin{array}{l}\text { a. Document reviews will be conducted in accordance with the FFA/CO (DOE-ID 1991, Part VIII). } \\
\text { b. The draft O\&M report will be prepared at the end of each calendar year. }\end{array}$} \\
\hline \multicolumn{3}{|c|}{$\begin{array}{l}\text { N/A = not applicable } \\
\text { INTEC = Idaho Nuclear Technology and Engineering Center } \\
\text { O\&M = operations and maintenance } \\
\text { RD/RA = remedial design/remedial action }\end{array}$} \\
\hline
\end{tabular}

A more detailed schedule for deliverables will be provided in the appropriate RD/RA work plan, and any changes in the working schedule and content from this SOW will be noted. 


\section{STRATEGY AND PLANS FOR EXPEDITING}

The OU 3-14 RD/RA goal is to perform the work in a timely, safe, efficient, and cost-effective manner, including:

- Using lump sum and competitive bid procurement methods for each action

- $\quad$ Streamlining the document preparation and review process by conducting concurrent activities and expedited reviews

- Working closely with the Agencies for quick resolution of issues

- $\quad$ Optimizing construction efficiency and productivity by scheduling field activities during summer weather.

The Agencies will reach consensus on the scope of the remedial design approaches and contents through preliminary design meetings and conference-call meetings, as necessary.

\section{COST ESTIMATE}

The estimated costs for the OU 3-14 RD/RA are listed in Tables 2 and 3 and summarized in Table 4. The estimate, in present-day dollars with a final conversion in net present value cost, includes both direct and indirect costs associated with design and construction. Direct costs include equipment, construction, and operation activities. Indirect costs include construction management, project management, and management reserve. Actual costs will be based on the final design and detailed cost itemization.

Table 2. Estimated capital cost of the Operable Unit 3-14 final remediation.

\begin{tabular}{lcc}
\hline \multicolumn{1}{c}{ Description of Capital Cost } & $\begin{array}{c}\text { Present Day } \\
\text { Cost (Phases I and II) }\end{array}$ & $\begin{array}{c}\text { Present Day } \\
\text { Cost (Phase III) }\end{array}$ \\
\hline Remedial Design & $\$ 268,500$ & $\$ 268,500$ \\
Remediation/Technical Support Activities & $\$ 161,500$ & $\$ 161,500$ \\
Remedial Action & $\$ 4,499,806$ & $\$ 4,542,000$ \\
Remedial Action Report & $\$ 174,500$ & $\$ 174,500$ \\
Professional/Technical Services & $\$ 369,500$ & $\$ 369,500$ \\
Subtotal Capital Cost & $\$ 5,473,806$ & $\$ 5,516,000$ \\
\hline Total Capital Cost & \multicolumn{2}{|c|}{} \\
\hline
\end{tabular}


Table 3. Estimated operations and maintenance and periodic cost of the Operable Unit 3-14 final remediation.

\begin{tabular}{lcc}
\hline \multicolumn{1}{c}{ Description of Operation and Maintenance Cost } & $\begin{array}{c}\text { Estimated Cost } \\
\text { (Annual) }\end{array}$ & $\begin{array}{c}\text { Extended Cost } \\
\text { (Life of Project) }\end{array}$ \\
\hline O\&M Activities & $\$ 96,000$ & \\
Surveillance and Monitoring & $\$ 157,000$ & \\
Infiltration Controls & $\$ 240,975$ & \\
Institutional Controls & $\$ 16,000$ & \\
\hline Total O\&M Cost & $\mathbf{\$ 5 0 9 , 9 7 5}$ & $\mathbf{\$ 2 2 , 1 5 2 , 9 6 1}$ \\
\multicolumn{1}{c}{ Description of Periodic Cost } & & \\
Construction/O\&M Activities (periodic) & $\$ 126,000$ & \\
Professional/Technical Services (five-year reviews) & $\$ 52,000$ & \\
Update Institutional Controls Plan (annual) & $\$ 21,000$ & \\
\hline Total Periodic Cost & $\mathbf{\$ 1 9 9 , 0 0 0}$ & $\mathbf{\$ 1 3 , 1 3 7 , 0 0 0}$ \\
\hline O\&M= operations and maintenance & & \\
\hline
\end{tabular}

Table 4. Summary of costs of the Operable Unit 3-14 final remediation.

\begin{tabular}{lc}
\hline \multicolumn{1}{c}{ Description of Cost } & Estimated Cost \\
\hline Total Capital Cost & $10,989,806$ \\
Total O\&M Cost & $22,152,961$ \\
Total Periodic Cost & $13,137,000$ \\
Total Project Cost in Present Value & $\mathbf{\$ 4 6 , 2 7 9 , 7 6 7}$ \\
Total Project Cost in Net Present Value & $\mathbf{\$ 1 4 , 7 7 1 , 0 0 0}$ \\
\hline $\begin{array}{l}\text { a. Present value costs include an average 19.8\% contingency. } \\
\text { b. Net present value in 2006 dollars. Net present value adjusts the value of a dollar today by the value of that same dollar in the future after } \\
\text { accounting for return and inflation. Estimated accuracy is }+50 \text { to -30\%.. A 6.5\% discount rate used to calculate net present value. } \\
\text { O\&M = operations and maintenance }\end{array}$ \\
\hline
\end{tabular}

Detained cost estimates will be provided in each work plan. Refinement and revision of these estimates will be conducted during each phase of remedial design. In accordance with the FFA/CO, it is assumed that the funding necessary to implement and carry out the remedial design and remedial action activities identified in this SOW will be appropriated to DOE-ID by Congress.

\section{REGULATORY REQUIREMENTS}

Under CERCLA (42 USC § 9601[121]), response actions conducted entirely onsite are exempt from obtaining federal, state, or local permits, but are required to comply with the substantive aspects of the ARARs specified for the site. The selected remedy will comply with the ARARs and achieve the performance standards specified by the OU 3-14 ROD (DOE-ID 2007 - Table 13-1). 


\section{DESIGN APPROVAL PROCEDURES AND REQUIREMENTS}

The FFA/CO (DOE-ID 1991) describes procedures and requirements for approving the remedial design documents. The deliverables identified in Sections 4 and 5 will be reviewed for the following elements.

- $\quad$ Compliance with ARARs

- $\quad$ Use of currently accepted environmental control measures and technology

- $\quad$ Adequacy of the design plans

- $\quad$ Consistency with the OU 3-14 ROD

- Implementability

- $\quad$ Accuracy of the cost estimate

- Use of currently accepted practices and techniques

- Environmental impacts.

DOE-ID approves and accepts the remedial design with concurrence from EPA and DEQ.

\subsection{Plans for Disposition of Changed Conditions}

Changes from planned conditions inevitably will occur during the execution of the remedial design and the remedial action. Identification and rapid disposition of both minor and significant changes is critical to successful project implementation under the accelerated schedule for remedial action. As a result, the protocol for disposition of changes occurring during the design phase will be:

- Any issues or potential changed condition arising from newly discovered site conditions or inconsistencies discovered in existing documentation (e.g., RI/FS and ROD) will be brought to the attention of the Agencies. Items of significant importance may be addressed in impromptu conference calls and/or meetings. Agency agreement on how to resolve issues or disposition resulting changes will be recorded in the conference call minutes or by e-mail. Changes that may affect the ROD will be addressed per the FFA/CO established protocol (DOE-ID 1991).

The protocol for disposition of changes occurring during the remedial action will be:

- Issues and potential changes will be identified to the Agencies for discussion in regular or impromptu conference calls. Resulting changes to RD/RA documents will be provided to the Agencies for concurrence and remedial action will be allowed to continue based on this concurrence. Agency agreement on how to resolve issues and concurrence on resulting document changes will be recorded in the conference call minutes or by e-mail. Subsequent revision to $\mathrm{RD} / \mathrm{RA}$ documents to incorporate the changes will note that Agency concurrence on the change was obtained and reference the conference call where the concurrence was documented. 


\section{CORRELATION BETWEEN PLANS AND SPECIFICATIONS}

Project procedures will ensure general correlation between the drawings and the technical specifications for OU 3-14 RD/RA activities. Before approval, the RD/RA project manager will review drawings and specifications. Any changes made after final approval and signatures will require a review and approval by the same individuals who performed the original review and approval or by their designees or replacements. For environmental, safety and health, and quality assurance reviews, verification of the completeness and correctness of a drawing achieves the following objectives.

- Ensures that the drawing reflects the design intent as expressed in design input documents, calculations, and sketches

- Ensures that the drawing expresses the requirements of the codes and standards in the design criteria

- $\quad$ Provides resolution of any conflicts between the data shown on the drawings and specifications and verification that the data are included in other pertinent drawings or specifications

- $\quad$ Presents the information clearly, completely, and accurately.

The Agencies will conduct preliminary design meetings to ensure integration of and consistency between the drawings and technical specifications. The subsequent design submittals will build on the initial design submittals.

\section{COMMUNITY RELATIONS PLAN}

The OU 3-14 remedial action will be conducted in accordance with the INEEL Community Relations Plan (DOE/NE-ID 2004b) or subsequent version, which describes various community relations activities and additional INL Site-specific activities that may occur during the course of this project. The requirements for remedial design and remedial action elements of the INEEL Community Relations Plan are found in 40 CFR 300.435(c) of the National Oil and Hazardous Substances Pollution Contingency Plan. Periodic updates will be provided of this project in accordance with the community relations plan.

The following subsections contain specific community relations activities that will be performed.

\subsection{Citizens Advisory Board Meetings}

Meetings will be held with Citizens Advisory Board members to discuss the plans and progress of the RD/RA process as deemed necessary. The Citizens Advisory Board may provide input and recommendations on the deliverables that are specified in this SOW.

\subsection{Administrative Record}

All major-deliverables and correspondence affecting decisions will be maintained in the Administrative Record for WAG 3. 


\section{REFERENCES}

40 CFR 300, 2006, "National Oil and Hazardous Substances Pollution Contingency Plan," Code of Federal Regulations, Office of the Federal Register, October 2006.

42 USC § 9620, 2004, “Federal Facilities,” United States Code, January 19, 2004.

54 FR 48184, 1989, "National Priorities List of Uncontrolled Hazardous Waste Sites; Final Rule," Federal Register, U.S. Environmental Protection Agency, November 21, 1989.

DOE, 2002, Idaho High-Level Waste and Facilities Disposition Final Environmental Impact Statement, DOE/EIS-0287, U.S. Department of Energy, September 2002. Available online at http://www.eh.doe.gov/NEPA/eis/eis0287/0287toc.html.

DOE, 2005, Supplement Analysis for the Idaho High-Level Waste and Facilities Disposition Final Environmental Impact Statement, DOE/EIS-0287-SA-01, U.S. Department of Energy, June 2005.

DOE-ID, 1991, Federal Facility Agreement and Consent Order for the Idaho National Engineering Laboratory, Administrative Docket No. 1088-06-29-120, U.S. Department of Energy Idaho Operations Office; U.S. Environmental Protection Agency, Region 10; Idaho Department of Health and Welfare, December 4, 1991.

DOE-ID, 1997a, Comprehensive RI/FS for the Idaho Chemical Processing Plant OU 3-13 at the INEEL_Part A, RI/BRA Report (Final), DOE/ID-10534, U.S. Department of Energy Idaho Operations Office, November 1997. Available online at http://ar.inel.gov/

DOE-ID, 1997b, Comprehensive RI/FS for the Idaho Chemical Processing Plant OU 3-13 at the INEEL - Part B, FS Report (Final), DOE/ID-10572, U.S. Department of Energy Idaho Operations Office, November 1997.

DOE-ID, 1999, Final Record of Decision, Idaho Nuclear Technology and Engineering Center, Operable Unit 3-13, Idaho National Engineering and Environmental Laboratory, Idaho Falls, Idaho, DOE/ID-10660, Rev. 0, U.S. Environmental Protection Agency, Idaho Department of Environmental Quality, U.S. Department of Energy Idaho Operations Office, October 1999.

DOE-ID, 2003, Remedial Design/Remedial Action Work Plan for Group 1 Tank Farm Interim Action, DOE/ID-10772, Rev. 1, U.S. Department of Energy Idaho Operations Office, September 2003.

DOE/NE-ID, 2004a, Idaho National Engineering and Environmental Laboratory Sitewide Five-Year Review Plan for CERCLA Response Actions, DOE-NE-ID 11125, Rev. 1.

DOE/NE-ID, 2004b, Community Relations Plan: A Guide to Public Involvement in the CERCLA Cleanup Program at the INEEL, DOE/NE-ID-11149, Rev. 0.

DOE/NE-ID, 2006a, Operable Unit 3-14 Tank Farm Soil and Groundwater Remedial Investigation/Baseline Risk Assessment, DOE/NE-ID-11227, Rev. 0, U.S. Department of Energy Idaho Operations Office, April 2006

DOE/NE-ID, 2006b, Five-Year Review of CERCLA Response Actions at the Idaho National Laboratory, DOE/NE-ID-11201, Rev. 1, U.S. Department of Energy Idaho Operations Office, June 2006 
DOE-ID, 2007, Record of Decision for Tank Farm Soil and INTEC Groundwater, Operable Unit 3-14 Idaho Cleanup Project, Idaho National Laboratory Site, Idaho Falls, Idaho, DOE/ID-11296, Rev. 0, U.S. Department of Energy Idaho Operations Office, May 2007. 


\begin{abstract}
Appendix A
Waste Area Group 3 Operable Unit 3-14

Remedial Design/Remedial Action Working Schedule
\end{abstract}


Table A-1. WAG 3 OU 3-14 Remedial Design/Remedial Action Working Schedule.

\begin{tabular}{|c|c|c|}
\hline Task Name & Start & Finish \\
\hline OU 3-14 Remedial Action & $06 / 1 / 07$ & $05 / 11 / 37$ \\
\hline OU 3-14 RD/RA Work Plan & $06 / 1 / 07$ & $07 / 26 / 08$ \\
\hline Prepare draft RD/RA work plan & $06 / 1 / 07$ & $02 / 21 / 08$ \\
\hline Submit OU 3-14 Draft RD/RA WP to Agencies & $02 / 21 / 08$ & $02 / 21 / 08$ \\
\hline Draft OU 3-14 RD/RA WP Agency Review & $02 / 22 / 08$ & $04 / 07 / 08$ \\
\hline Resolve Draft OU 3-14 RD/RA WP Agency comments & $04 / 08 / 08$ & $05 / 23 / 08$ \\
\hline Submit Draft Final OU 3-14 RD/RA WP to Agencies & $05 / 24 / 08$ & $05 / 24 / 08$ \\
\hline Draft Final OU 3-14 RD/RA WP Agency Review & $05 / 25 / 08$ & $06 / 25 / 08$ \\
\hline Resolve Draft Final OU 3/14 RD/RA WP Agency comments & $06 / 26 / 08$ & $07 / 25 / 08$ \\
\hline Submit Final RD/RA WP to Agencies & $07 / 26 / 08$ & $07 / 26 / 08$ \\
\hline Remedial Action - Phase I (outside TFF) & $07 / 18 / 08$ & $11 / 9 / 10$ \\
\hline Additional Recharge Controls - FY08 & $07 / 18 / 08$ & $12 / 9 / 08$ \\
\hline Additional Recharge Controls - FY09 & $07 / 20 / 09$ & $12 / 9 / 09$ \\
\hline Pave outer recharge control zone - FY10 & $07 / 20 / 10$ & $11 / 9 / 10$ \\
\hline Remedial Action - Phase II (inside TFF) & $07 / 18 / 11$ & $09 / 11 / 12$ \\
\hline Prepare Phase II 90\% design & $07 / 18 / 11$ & $11 / 4 / 11$ \\
\hline Submit Draft Phase II Design & $11 / 4 / 11$ & $11 / 4 / 11$ \\
\hline Agency Review - Phase II Design & $11 / 7 / 11$ & $12 / 8 / 11$ \\
\hline Resolve Agency Comments - Phase II Design & $12 / 9 / 11$ & $01 / 12 / 12$ \\
\hline Submit Final Phase II Design & $01 / 12 / 12$ & $01 / 12 / 12$ \\
\hline Install Phase II Remedial Action $^{\mathrm{a}}$ & $01 / 13 / 12$ & $09 / 11 / 12$ \\
\hline OU 3-14 Phase I \& II Completion Report & $09 / 12 / 12$ & $02 / 20 / 13$ \\
\hline Prefinal inspection & $09 / 12 / 12$ & $10 / 9 / 12$ \\
\hline Submit Prefinal Inspection Report to Agencies & $10 / 9 / 12$ & $10 / 9 / 12$ \\
\hline Prepare Draft Completion Report & $10 / 10 / 12$ & $12 / 12 / 12$ \\
\hline Submit Draft Phase I \& II Completion Report to Agencies & $12 / 12 / 12$ & $12 / 12 / 12$ \\
\hline Draft Phase I \& II Completion Report Agency Review & $12 / 13 / 12$ & $01 / 21 / 13$ \\
\hline Resolve Draft Phase I \& II Completion Report Agency comments & $01 / 22 / 13$ & $02 / 20 / 13$ \\
\hline Submit Final Phase I \& II Completion Report to Agencies & $02 / 20 / 13$ & $02 / 20 / 13$ \\
\hline Remedial Action - Phase III (ET/CB) & $12 / 31 / 35$ & $11 / 5 / 36$ \\
\hline INTEC Closure $^{\mathrm{b}}$ & $12 / 31 / 35$ & $12 / 31 / 35$ \\
\hline Prepare Phase III 90\% design & $01 / 1 / 36$ & $03 / 24 / 36$ \\
\hline Submit Draft Phase III Design & $03 / 24 / 36$ & $03 / 24 / 36$ \\
\hline Agency Review - Phase III Design & $03 / 25 / 36$ & $04 / 23 / 36$ \\
\hline Resolve Agency Comments - Phase III Design & $04 / 24 / 36$ & $05 / 21 / 36$ \\
\hline Submit Final Phase III Design & $05 / 21 / 36$ & $05 / 21 / 36$ \\
\hline Install Phase III Remedial Action & $05 / 22 / 36$ & $11 / 5 / 36$ \\
\hline OU 3-14 RA Report & $11 / 6 / 36$ & $05 / 11 / 37$ \\
\hline Prefinal inspection - Phase III & $11 / 6 / 36$ & $11 / 19 / 36$ \\
\hline Prepare Draft Remedial Action Report & $11 / 20 / 36$ & $01 / 7 / 37$ \\
\hline Submit OU 3-14 Draft RA Report to Agencies & $01 / 7 / 37$ & $01 / 7 / 37$ \\
\hline Draft OU 3-14 RA Report Agency Review & $01 / 8 / 37$ & $02 / 20 / 37$ \\
\hline Resolve Draft OU 3-14 RA Report Agency comments & $02 / 23 / 37$ & $04 / 7 / 37$ \\
\hline Submit Draft Final OU 3-14 RA Report to Agencies & $04 / 7 / 37$ & $04 / 7 / 37$ \\
\hline Draft Final OU 3-14 RA Report Agency Review & $04 / 8 / 37$ & $04 / 23 / 37$ \\
\hline Resolve Draft Final OU 3-14 RA Report Agency comments & $04 / 24 / 37$ & $05 / 11 / 37$ \\
\hline Submit Final RA Report to Agencies & $05 / 11 / 37$ & $05 / 11 / 37$ \\
\hline \multicolumn{3}{|c|}{$\begin{array}{l}\text { a. Installation of the Phase II Remedial Action is planned for completion by September 2012. However, if tank farm facility closure is delayed, paving } \\
\text { of the tank farm west of the } 2012 \text { Line (as shown in Figure 2) will be completed by September 2012. The remainder of the tank farm area will be paved } \\
\text { following tank farm facility closure. } \\
\text { b. The listed date for INTEC closure is estimated for planning purposes. }\end{array}$} \\
\hline
\end{tabular}

